УДК 316.477

DOI: https://doi.org/10.33120/ssj.vi46(49).168

\author{
Мяленко Вікторія Володимирівна \\ кандидат психологічних наук, старший науковий співробітник \\ лабораторії психології мас та спільнот, \\ Інститут соціальної та політичної психології \\ НАПН України, \\ м. Київ, Україна \\ ORCID ID 0000-0002-5527-6958 \\ viktoriia.mialenko@ispp.org.ua
}

\title{
ПСИХОЛОГІЧНІ ОСОБЛИВОСТІ КОНСТРУЮВАННЯ ОБРАЗІВ ЛГБТ-ЛЮДЕЙ У СПРИЙНЯТТІ ЇХНІХ БАТЬКІВ ТА ВЧИТЕЛІВ
}

\begin{abstract}
Зазвичай більшість людей оцінюють себе як толерантних. Розбіжність між декларуванням цього і реальними кейсами життя стала об'єктом нашого дослідження. Якісне дослідження 3 використанням глибинних інтерв'ю дало змогу проаналізувати та диференціювати образи гея, лесбійки і трансгендерної людини в сприйнятті батьків ЛГБТдітей та освітніх працівників. Батьки, на противагу вчителям, схильні ідеалізувати власних дітей, приписуючи їм надзвичайний розум, творчі здібності, досконалість та красу порівняно 3 їхніми гетеросексуальними однолітками. На нашу думку, це свідчить про незавершеність процесу прийняття власної дитини та іiї сексуальної орієнтації. Почасти батьки відтворювали звичні стереотипи щодо ЛГБТ-людей, наділяючи їх тими самими рисами, які зазвичай приписуються їм в масовій свідомості, проте почасти і відкидали ці стереотипи, визнаючи, що геї та лесбійки бувають дуже різними. Найменш стереотипізованим виявився образ трансгендерної людини. Можливо, це пов'язано з тим, що в масовій свідомості цей образ має доволі обмежені, фрагментарні та грубі зразки. Описи сімей, у яких є ЛГБТ-людина, доволі типові та узагальнені. Наявність будь-якої проблеми ніколи не прив'язується до сім’ї; можна припустити, що за такими інтерпретаціями приховується почуття провини батьків за те, що їхні діти виявилися “інакшими”. Освітні працівники, характеризуючи образи ЛГБТ-людей, відтворюють поширені в масовій свідомості міфи i стереотипи щодо ЛГБТ-спільноти. Так, геї в їхніх описах переважно жіночні, лесбійки - маскулінні, трансгендери - театральні і буфонадні. Серед феноменів сприйняття ЛГБТ-людей учителями слід відмітити “невидимість” для них цих осіб і неусвідомлювану щодо них нетолерантність. "Невидимість" проявляється в тому, що, на думку частини освітян, у їхніх школах та містах ЛГБТ-осіб немає, а “неусвідомлювана” нетолерантність - в обов'язковому декларуванні особою своєї толерантності з необов'язковим дотриманням такої заяви. Основний напрям подальших досліджень передбачає розроблення соціально-психологічної тренінгової технології підвищення толерантності щодо ЛГБТ-осіб.
\end{abstract}

Ключові слова: спільнота; ЛГБТ-спільнота; толерантність; дискримінація; образ ЛГБТлюдей; сприйняття.

\section{PSYCHOLOGICAL PECULIARITIES OF IMAGES CONSTRUCTING FOR LGBT PEOPLE IN THE PERCEPTION OF THEIR PARENTS AND TEACHERS}

\author{
Victoria V. Mialenko \\ Ph.D. in Psychology, Senior Research Associate, \\ Laboratory of Psychology of Masses and Communities, \\ Institute for Social and Political Psychology, NAES of Ukraine, \\ Kyiv, Ukraine
}


ORCID ID 0000-0002-5527-6958

viktoriia.mialenko@ispp.org.ua

Usually, most people consider themselves tolerant. The discrepancy between declaring this and real-life cases is the object of the study. Qualitative research with in-depth interviews made it possible to analyze and differentiate the images of gay, lesbian, and transgender people in perceptions of parents of LGBT children and educators. Parents, in contrast to teachers, tend to idealize their own children by attributing to them extraordinary intelligence, creativity, perfection, and beauty compared to their heterosexual peers. In our opinion, this indicates the incompleteness of the acceptance process of their own child and sexual orientation. Predominantly, parents recreated the usual stereotypes about LGBT people, giving them the same traits that are usually attributed to them in the mass consciousness, but somewhat they rejected these stereotypes, acknowledging that gays and lesbians are very different. The image of a transgender person was the least stereotyped. Perhaps because in the mass consciousness this image has quite limited, fragmentary, and crude patterns. Descriptions of families with an LGBT person are fairly typical and generalized. The presence of any problems is never tied to the family; it can be assumed that such interpretations hide the guilt of parents that their children turned out to be "different". Educators, when characterizing the images of LGBT people, reproduce the widespread myths and stereotypes about the LGBT community. Thus, gays in their descriptions are mostly feminine, lesbians - masculine, transgenders - theatrical, and buffoonery. Among the phenomena of LGBT people perception by teachers, there should be noted the "invisibility" of these people for them and unconscious intolerance towards them. "Invisibility" is displayed in the fact that, according to some educators, there are no LGBT people in their schools and cities. Moreover, "unconscious" intolerance is displayed in the mandatory declaration of their own tolerance with optional adherence to such a statement. The development of socio-psychological training technology to increase tolerance for LGBT people is expected in further research.

Keywords: community; LGBT community; tolerance; discrimination; LGBT people image; perception.

Постановка проблеми. Вплив політики “традиційних" цінностей, посилення маргіналізації "особливих" груп населення, намагання зберегти привілеї більшості щодо будь-якої меншості призводять до того, що все “інше”, “відмінне” і “несхоже” йде в тінь і стає невидимим або позначається як менш значуще, не гідне уваги. Проте сучасне суспільство змінюється, деякі спільноти стають більш видимими для більшості, що викликає доволі різну реакцію. Яким чином ми сприймаємо інших, відмінних від нас? Наскільки ми толерантні до інакшості? I якщо ми сприймаємо або не сприймаємо когось, то який його образ ми малюємо?

Аналіз останніх досліджень і публікацій, виокремлення нерозв'язаних частин загальної проблеми. Проблематика ставлення до ЛГБТ-спільноти в українському соціумі стала досліджуватися не так давно, тому грунтовних академічних досліджень майже немає. Західна психологічна наука встигла накопичити тут значний доробок (Florack, Scarabis, \& Gosejohann, 2005; Lamar, \& Kite,1998; Skinner, \& Goodfriend, 2009; Nama, MacPherson, \& McMillan, 2017; Nцlke, 2018). Що ж до російськомовного простору, то тут можна виокремити два найтиповіших полюси дослідження цієї теми - проблему дискримінації ЛГБТ-спільноти і проблему загрози, які вона несе. Так, наприклад, І. Кон, аналізуючи особливості російської гомофобії, зауважує, що на образ ЛГБТ-особи накладається вплив цілої низки факторів - від власного досвіду спілкування i соціально-демографічних факторів до антизахідної спрямованості (Кон, 2007).

Вплив 3МІ, безумовно, також причетний до формування певного образу. Так, Р. Осін, досліджуючи вплив ЗМІ на сприйняття ЛГБТ-спільноти, зауважує, що вони породжують доволі суперечливе ставлення до ЛГБТ-осіб. У більшості випадків респонденти приписують ЛГБТ-особі такі вербальні і невербальні способи спілкування, зовнішній вигляд, поведінку в цілому, які свідчать про інфантильність, манірність, демонстративність щодо власної сексуальності, непристойність поглядів і дотику до осіб своєї ж статі, занадто кричущий одяг 
та макіяж (Осин, 2019). Розглядаючи образ ЛГБТ-спільноти в масовій свідомості, Ю. Орлова зазначає, що ЛГБТ-особу аналізують через концепт пороку та девіантної поведінки, використовуючи стигматизувальні та віктимні елементи (Орлова, \& Осин, 2019). Досить поширений стереотип, що високий рівень гомофобії трапляється лише в невеличких містах і селах, проте дослідження I. Ушакової та Е. Кіреєва свідчать про протилежне. Так, учені зафіксували доволі негативні стереотипи та образи ЛГБТ-осіб у жителів Москви, при цьому інформацію про трансгендерних осіб москвичі отримували в мережі інтернет, ТБ-шоу, кіно і на ТБ-передачах (Ушакова, \& Киреев, 2017).

Мета статті. Ставлення українського соціуму до ЛГБТ-спільноти доволі мало досліджене, тому нас цікавили питання конструювання образу гея, лесбійки і трансгендерної людини в сприйнятті їхніх батьків та вчителів, психологічні особливості сприйняття в обох групах.

Виклад основного матеріалу дослідження. Щоб з'ясувати особливості ставлення батьків та освітніх працівників до ЛГБТ-дітей, було проведено 20 глибинних інтерв'ю. Обстежуваними стали освітні працівники (педагоги, шкільні психологи) і матері геїв, лесбійок, трансгендерних людей віком від 34 до 60 років. Тривалість інтерв'ю становила до 1,5 години. Польові роботи проводилися з 10 вересня по 5 жовтня 2019 року.

Нижче наведено результати аналізу відповідей щодо образу геїв, лесбійок i трансгендерних людей. Ми запитували респондентів: 1. Якими були ваші перші вербальні несвідомі реакції щодо геїв, лесбійок і трансгендерів? 2. Як виглядають типові гей, лесбійка, трансгендер? Які вони за характером? 3 яких сімей походять? Які професії обирають? 3 ким товаришують?

Усі ці питання знаходили відгук у наших респондентів, і вони наводили необхідну кількість асоціацій (при цьому майже не виходили за межі інструкції). Слід відмітити, утім, невиразну тенденцію: респонденти намагалися давати менше асоціацій, пов'язаних 3 трансгендерними людьми, що може свідчити про деяку обережність обстежуваних, з одного боку, і про те, що в них немає тут великої кількості готових зразків у полі соціальних уявлень - з другого.

Сформовані соціальні уявлення респондентів характеризуються доволі високим рівнем узгодженості. Загалом отримані результати дають підстави припустити, що високий рівень ідеалізації батьками власних ЛГБТ-дітей пов'язаний з тим, що процес прийняття ними сексуальної орієнтації або гендеру дитини ще триває. Натомість особливість конструювання образу ЛГБТ-дитини в середовищі освітніх працівників полягала в тому, що перш за все вони намагалися пред’явити власну толерантність.

Образ гомосексуала у сприйнятті батьків ЛГБТ-дітей. Описуючи зовнішність хлопця, батьки відзначають його красу, довершеність, акуратність, жіночність, уміння гарно вдягатись, незвичність, своєрідність, нетиповість зовнішнього вигляду. Гея відрізняють особливі жести руками, манірність, хода, вимова. Мами підмітили, що геї бувають двох типів - фемінні або маскулінні. Проте в їхніх описах найчастіше фігурував жіночний образ; як правило, це образ елітарного, “вищого” за інших, майже аристократичного юнака.

Асоціації, які ми віднесли до характерологічних рис геїв, змальовують освічену, виховану, розумну, творчу, креативну, ніжну, цікаву, цілеспрямовану, розвинену та еталонну людину. Вони мають добру і м'яку вдачу. Доволі часто батьки відзначали, що порівняно 3 “натуралами" геї більш творчі. На їхню думку, найчастіше гомосексуали обирають творчі професії і стають відомими. Батьки, описуючи, чим гей відрізняється від гетеросексуального хлопця, пояснювали, що гомосексуалам подобаються лише хлопці, вони по-іншому дивляться на жінок, не використовують флірт щодо них.

Найбільше батьків непокоїло те, що геїв дискримінують, не приймають у суспільстві; що бути гомосексуалом небезпечно - їм потрібно критися або виїжджати; що батькам треба захищати власну дитину. Батьки виказували страхи за їхнє здоров'я, життя, долю. Найголовнішою була тема страху за власних дітей та їхню безпеку в українському суспільстві. 
Описуючи сім’ю хлопця-гея, батьки найчастіше говорили, що типового варіанта немає, що буває по-різному: іноді дитина росте в повній сім’і, іноді - 3 мамою. Проблемні відносини, деструктивні сім’ї або якісь сімейні негаразди не згадувалися.

На думку батьків ЛГБТ-дітей, геї найчастіше спілкуються з геями, вони уникають лесбійок і трансгендерних людей, з гетеросексуалами їм нецікаво, а часом небезпечно.

Образ лесбійки у сприйнятті батьків ЛГБТ-дітей. Більшість батьків зазначали, що сучасна мода утруднює визначення орієнтації жінки, оскільки значна більшість дівчат яскраво вдягається, фарбує волосся в неймовірні кольори, робить пірсинг і татуювання. Проте можна виокремити два яскраві типажі - “буч” і “фем”. “Буч” носить коротку зачіску, одяг, схожий на чоловічий. На противагу їй, “фем” - гіпержіночна, прекрасна, витончена, ніжна, “така дівчинка-дівчинка”, - як зауважила одна мама.

Описи характеру також містять дві ролі, хоча батьки зазначають, що лесбійки бувають дуже різні. До речі, стосовно гомосексуальних чоловіків таких зауважень не було. Перший тип характеру - тип активної, цілеспрямованої, розумної, пробивної, іноді агресивної дівчини. Другий тип - тип ніжної, зворушливої, чуйної, милої, чутливої, вихованої, відкритої до спілкування дівчини, готової дати пораду, надати допомогу; такі дівчата більш вразливі і розумні (порівняно з гетеросексуальними особами).

Якщо аналізувати дискримінаційні практики щодо геїв і лесбійок, то, на думку батьків, гомосексуальних жінок дискримінують набагато менше. Вони здаються сексуально надзвичайно привабливими, й оточення, інші люди не бачать у цьому проблеми або взагалі сприймають це байдуже. Проте, зауважимо, такі образи не виникали у батьків лесбійок.

Сім'ю лесбійки описують як звичайну, таку саму, як в інших; наявність обох батьків або якихось негараздів не згадується.

На думку обстежуваних, лесбійки прагнуть спілкуватися з такими самими дівчатами, причому чоловіки не викликають у них відразу. Зазвичай вони уникають інших ЛГБТ-людей або гетеросексуалів. За словами однієї мами, “їм не подобається змішуватися”.

Образ трансгендерної людини у сприйнятті батьків ЛГБТ-дітей. Якщо щодо геїв і лесбійок можна відстежити як певні стереотипи, так i ïx заперечення, то образ трансгендерної людини викликає більше емоційних реакцій - спантеличення, дисонансу, жалю, відрази, співчуття тощо. Якщо ж говорити про образ трансгендерної людини в очах самої трансгендерної особи, то навіть деякі з них засвідчують, що довго вагалися щодо “переходу": їм здавалося, що Т-людина має виглядати як напівоголена жінка з бразильського карнавалу з інтенсивним макіяжем і в пір'ї.

Асоціативний ряд щодо трансгендерів майже не містить описів зовнішності. Іноді траплялися асоціації, що ці люди носять одяг представників протилежної статі. Тобто насправді обстежувані описували транссексуалів. Найчастіше цій людині приписували чоловічий гендер, тобто змальовували образ MtF (Female-to-Male).

Батьки рідко порівнювали геїв і лесбійок між собою, часто зазначали, що відчувають однакові емоції та почуття як щодо геїв, так і щодо лесбійок, при цьому частіше порівнювали групу геїв і лесбійок з транслюдьми. Так, наприклад, для них важливо було знайти “причину" того, як люди “стають” трансгендерними. Як найтиповіші причини вони називали: психічну травму; хворобу; розчарування в комусь або чомусь; значну кількість проблем (мається на увазі психологічних і/або психічних); бажання епатувати; долю, фатум, рок, генетичні причини. Іноді батьки зазначали, що це може бути тимчасова проблема $\mathrm{i}$ дитина “переросте".

Серед психологічних особливостей Т-людей найчастіше згадували незрозумілість, відстороненість, дивакуватість, епатаж, непередбачуваність (обстежувані говорили, що не знають, чого чекати від них). Їм приписували гомосексуальну орієнтацію, пояснюючи, що насправді хлопець - гей, проте не може прийняти свою орієнтацію, тому хоче змінити стать. Деякі батьки сумніваються в “справжності” феномену, думають, що потрібно було “більше ременя". 
До найбільш згадуваних щодо трансгендерних людей емоцій та почуттів слід віднести: спантеличеність; розгубленість; страх; “хорошу, добру жалість”; бажання відсторонитись; відразу; бажання підтримати; розуміння, що їм досить важко; нерозуміння, як потрібно спілкуватися з транслюдьми; бажання захиститися від них; скарги, що “сердце від них болить”.

Батьки, відтворюючи образи геїв і лесбійок, говорили про те, як їм важко, як їх дискримінують, не приймають та відкидають. Проте слово “булінг” не прозвучало ні разу. Стосовно транслюдей першою або другою асоціацією була проблема неприйняття, важкості їхнього становища, ізольованості в суспільстві, дискримінації, цькування. I саме щодо цієї групи найчастіше виявлялися поривання “якось допомогти”, “якось підтримати”, “підставити плече".

Сім'я трансгендерної людини описувалася як типова і звичайна, без негараздів, або ж iз типовими, як і у всіх, негараздами. Якщо дитина з проблемами, то висловлювалося нерозуміння, звідки з'явилися ці проблеми («але точно не із сім’ї»).

Отже, аналіз образів геїв, лесбійок і трансгендерних людей у сприйнятті їхніми батьками дає підстави зробити припущення про гіперідеалізацію ними власних дітей і про те, що процес прийняття власних дітей, їхньої сексуальної орієнтації триває. Так, можна зауважити, що якась частина батьків справді ідеалізує своїх дітей, тоді як від матері гетеросексуальної дитини майже немає шансів почути: "Мій хлопчик особливий, він набагато кращий за гомосексуалів. Він і більш розумний, і більш уважний, а талановитий який! Гомосексуальні діти такими не бувають!".

Дивним видається те, що, по суті, не фіксуються асоціації, пов'язані із сексом, сексуальною орієнтацією. Цієї сфери життя дітей наче не існує. Батьки робили акцент на надзвичайному розумі, творчості та досягненнях їхніх дітей порівняно з гетеросексуальними ровесниками. Почасти батьки відтворювали звичні стереотипи щодо ЛГБТ-людей, наділяючи їх тими самими рисами, які приписують їм у масовій свідомості, проте почасти i відкидали ці стереотипи, визнаючи, що геї і лесбійки бувають дуже різними.

Слід зазначити, що батьки продемонстрували доволі високий рівень поінформованості щодо ЛГБТ-теми. Частина 3 них намагалися розібратися, чому їхні діти такі, тому багато читали. У їхньому сприйнятті не їхні діти несуть загрозу суспільству, а нетолерантне суспільство є загрозою для їхніх дітей.

Найменш стереотипізованим виявився образ трансгендерної людини. Можливо, це пов'язано з тим, що в масовій свідомості цей образ має доволі обмежені, фрагментарні i грубі зразки. Образ трансгендерної людини більше окреслював ставлення батьків до нього, ніж цілісне сприйняття певного феномену. Відносно Т-людей батьки відчувають розгубленість, бажання допомогти або ж, навпаки, неприйняття. На думку обстежуваних, найбільше дискримінують саме транслюдей.

Цікавим видається те, що описи сімей є доволі типовими, узагальненими («як у всіх, не краще і не гірше»). Якщо констатувалася навність якоїсь проблеми, іiі ніколи не прив'язували до сім'ї. Можна припустити, що за такими асоціаціями та інтерпретаціями приховується почуття провини батьків за те, що їхні діти виявилися такими.

Образ гомосексуала у сприйнятті освітніх працівників. Описуючи зовнішність такого юнака, обстежувані перш за все вказують на його доглянутість; заклопотаність власним зовнішнім виглядом; особливий, ретельно підібраний гардероб; намагання підкреслити свою сексуальність, красу; епатаж, манірність, певні жести руками, посмішку, манеру вимови, особливу самопрезентацію, сексуальність, метросексуальність, намагання привернути до себе увагу. Найчастіше гей асоціюється у них з нетрадиційними сексуальними відносинами, сексом, ненормативністю, особливостями, чоловіками, проблемами, коханням, нерозумінням.

Описуючи характер гомосексуала, освітяни найчастіше використовують слова: милий, м'який, інакший, розумний, нещасний, звичайний, менш духовний (порівняно 3 гетеросексуалами), цікавий, людина 3 іншими поглядами, інтересами, потребами. Іноді цей 
образ персоніфікований, тоді вчителі називають конкретних осіб. На думку освітніх працівників, геї здебільшого обирають творчі, активні професії.

Привертає увагу й те, що вчителі намагаються моделювати життєвий шлях такої дитини, на відміну від батьків, яким, напевно, замислюватися про це (під час дослідження психологом) доволі боляче. На думку освітян, таким особам непросто пробиватися (і слово яке підібрали!) в житті, їм важко бути щасливими або вони і не будуть щасливими.

Моделюючи сім'ю гея, учителі найчастіше зазначають, що ці хлопчики виросли без батька, або з домінуючою матір'ю, або ж у проблемній сім’ї, або мали проблемні стосунки, або пережили насилля. Сексуальна орієнтація оцінюється як вибір людини, контрольована особливість, перевага, обраний шлях, неприродність, проблема духовності або моралі.

Частина вчителів зазначала, що в їхньому населеному пункті геїв або ЛГБТ-людей узагалі немає. Тобто ця частина нашого суспільства залишається для них невидимою 3 певних причин. Також, на думку освітян, геї віддають перевагу спілкуванню “зі своїми”.

Проте найвиразнішою особливістю ставлення освітніх працівників до ЛГБТ-людей виявилася підкреслена толерантність. Не всі вчителі вживають це слово, тому іноді звучало інше - “дипломатичність”. Ця толерантність не завжди є “справжньою, реальною”, проте завжди демонстративною. Так, учителі говорили: “я ставлюся до них спокійно"; "вони не викликають у мене відрази”; “вони мені не неприємні”; “вони мене абсолютно не чіпляють”; “у мене також є проблеми, не тільки їм складно!”. Або, наприклад, одна й та сама людина пояснювала, що вона толерантна і навіть готова спілкуватися, якщо така особа трапиться (звичайно, якщо ця людина не родич, бо родича вона не прийме). Проте далі людина говорить: “Він буде йти із закривавленою рукою і візьметься цією рукою за ручку в під'їзді, а потім за цю ж ручку візьмуться мої діти і заразяться СПІДом. Я не хочу жити з ними в одному під’їзді!”. В уяві цієї людини ЛГБТ-особа високоймовірно може бути носієм загрози ВІЛ. А цей цікавий феномен псевдотолерантності дає їй змогу утримувати позитивний образ Я і не усвідомлювати власну нетолерантність та непоінформованість. На нашу думку, ця неусвідомлювана нетолерантність, або приховувана дискримінація, стосується не тільки освітніх працівників, а й суспільства загалом.

На перший погляд, неусвідомлювана, приховувана нетолерантність виглядає не дуже “симпатично” і видається негативним феноменом. Проте люди намагаються бути толерантними, визнають це за цінність, ЛГБТ-особи є для них видимі та визнаються ними. Тому ми вважаємо це, безумовно, позитивним соціальним зрушенням.

Образ лесбійки у сприйнятті освітніх працівників. Описуючи зовнішність лесбійки, учителі відтворюють три образи. Перший: коротка зачіска, чоловічий стиль в одязі або вдягнена як хлопець, чоловічі манери і “замашки”, особливості поводження, іноді пірсинг і татуювання. Другий тип: сексуально приваблива, красуня, сексуально бентежить і чоловіків, і жінок, симпатична, відкрита, може мати руде волосся («руда бестія»). Третій тип: дівчина виглядає абсолютно звичайно, і доки вона себе "не здасть", ти іiі не вирахуєш. Або, як зауважила обстежувана, “проститутку простіше впізнати, ніж лесбійку”.

Найчастіші асоціації щодо лес бійок такі: спосіб життя, краса, секс, нещасна, мужикувата, просто жінка, кохання.

Освітянам доволі складно змоделювати характер або психологічні якості такої жінки. Найчастіше говорили, що вона сумна, нещасна, не зможе бути щасливою, нормальна /як усі /ненормальна, награється і повернеться до норми або вийде заміж, не зустріла “нормального чоловіка".

Що ж до рівня дискримінації лесбійок, то тут учителі погоджуються з батьками і говорять про те, що до лесбійок ставлення більш м'яке, ніж до геїв або трансгендерних людей.

Моделюючи сім'ю лесбійок, освітяни рідше говорили про звичайну, типову сім'ю, а найчастіше припускали наявність неповної сім'ї, проблеми в родині, наявність вітчима, досвід дитячого будинку, досвід дитячих втеч із сім’ї. Що ж до сексуальної орієнтації дівчини, то обстежувані припускали, що це особистий вибір, пошуки себе, експерименти, 
спосіб життя, проблеми 3 моральністю, досвід насилля або розбещення, вроджена особливість.

Коли ж ішлося про вибір професії та кола спілкування, обстежувані найчастіше зазначали, що тут немає якихось закономірностей і може бути досить по-різному.

Образ трансгендерної людини у сприйнятті освітніх працівників. Відтворюючи зовнішній образ Т-людини, вчителі змальовували два типи. Перший: театральний, буфонадний, коли чоловік перевдягається в жінку і це, абсолютно очевидно, виглядає комічно і викликає сміх. Другий тип: особа, яка не має прикметних, особливих рис, які іiі відрізняють, якась невизначена "сіра маса”, “немає картинки”.

Найчастіше освітяни наводили такі асоціації: “якась травма дитинства"; “незрозумілий, неприйнятний”; “такий вибір людини”; “вони самі себе не приймають”; “людина, яка пережила трагедію; щось погане”; “дві різні частини, які скріпили між собою (дві різні людини, два різних вагончики в одному, слово з двох коренів)”.

Як і батьки ЛГБТ-дітей, освітні працівники плутають трансгендерність і кросдресинг, що, напевно, нормально, і приписують трансгендерній особі чоловічий гендер (варіант FtM не був змодельований жодного разу).

Незрозумілість такої людини відображає й особливості опису іiі психологічних особливостей: наявність травми (травма дитинства, травмування впродовж усього життя, пережив трагедію), абсолютна очевидність певної ненормальності, дивакуватість, відстороненість, пригніченість, проблеми 3 духовністю, неприйнятість $\mathrm{i}$ собою, i суспільством, багато в чому собі відмовляє, нормальний / адекватний / такий, як і інші.

Ця категорія людей викликає найбільший емоційний відгук. Їх жаліють, не сприймають, відчувають до них відразу, їх хочуть підтримати і водночас відкидають, хочуть захистити, визнають їхнє складне становище і тиск суспільства, вони викликають почуття провини або сміх, їх не можна судити.

Сім'ям, де ростуть такі діти, зазвичай приписують проблемність, деструктивність, гіпо- або гіперопіку, неуміння виховувати взагалі. Освітяни моделювали ситуації, коли батьки хлопчика 3 дитинства перевдягали його в дівчинку, і він звик. Напевно, таким чином обстежувані намагаються осягнути кросдресинг дорослого чоловіка.

Отже, аналіз образів геїв, лесбійок і трансгендерних людей у сприйнятті освітніх працівників відтворює поширені міфи та стереотипи щодо ЛГБТ-спільноти в масовій свідомості. Геям переважно приписують жіночність, прикметними особливостями лесбійок вважають маскулінність, щодо трансгендерів очікують театральності та буфонади або взагалі не розуміють цього феномену.

На відміну від батьків, учителі асоціюють ЛГБТ-осіб із сексуальною сферою та визнають іiі наявність у таких людей. Також учителі, на відміну від батьків, не ідеалізують осіб з гомосексуальною орієнтацією, не приписують їм надзвичайний розум та красу, хоча й зізнаються, що, напевно, геї більш творчі, ніж гетеросексуали.

Також освітяни відтворили один з ефектів масової свідомості - “невидимість” ЛГБТосіб. Він виявився в тому, що вчителі стверджували, що в їхньому місті немає ані геїв, ані лесбійок, ані трансгендерів. (А в одному населеному пункті, на переконання респондента, їх ніколи і не було!).

Ще один цікавий феномен сучасного українського суспільства - неусвідомлювана нетолерантність, або прихована дискримінація. Ідеться про явище, коли людина насправді ніколи не замислювалась, що таке бути толерантним, як приймати відмінну від неї людину. Напевно, ці речі не потрапляли досі в коло уваги особи, не були для неї важливими. Радянські цінності передбачали, що “совєтська" людина повинна бути передбачувано правильною та відповідати комуністичним цінностям. Понад двадцять років самостійності нас вчили суб'єктності, і наразі ми досі вчимося сприймати інакшість. Тому загалом, 3 огляду на динаміку розвитку українського соціуму, вважаємо цей феномен таким, що свідчить про позитивні зміни. 
На нашу думку, можливою ознакою такої неусвідомлюваної нетолерантності є характеристика свого ставлення до ЛГБТ-людей від протилежного, коли вчителі говорили: “він не викликає у мене відразу”; “вони мене абсолютно не чіпляють”; “я не відсторонююся від таких людей, просто вони мені не трапляються”; “я не вважаю їх ненормальними”; “не можу сказати нічого поганого про них"; “вони не погані” тощо. На нашу думку, тут простежується констатація, що в суспільстві до таких людей можуть ставитися по-різному, проте вчитель ставиться добре. Іноді освітяни говорили: “Я вчитель, я не можу собі дозволити бути нетолерантним".

Висновки та перспективи подальших досліджень. За результатами якісного дослідження проаналізовано образи гея, лесбійки і трансгендерної людини у сприйнятті батьків ЛГБТ-дітей та освітніх працівників.

Особливості сприйняття батьками ЛГБТ-осіб полягає в ідеалізації власних дітей, що може свідчити про те, що процес прийняття їхньої сексуальної орієнтації триває. Водночас сексуальність власних дітей завжди відкидається. Попри доволі високий рівень поінформованості щодо ЛГБТ-теми батьки відтворювали звичні для масової свідомості стереотипи, виняток становить фрагментарний, грубий образ трансгендерної людини. Моделюючи сімейний “анамнез” ЛГБТ-людини, батьки, на відміну від освітніх працівників, не приписували сім’ям якихось деструкцій.

Освітні працівники відтворюють типові стереотипи щодо ЛГБТ-осіб, приписуючи геям переважно жіночність, лесбійкам - переважно маскулінність, транслюдям - певну театральність і кросдресинг. Серед виразних феноменів сприйняття слід відзначити "невидимість" ЛГБТ-осіб та неусвідомлювану нетолерантність щодо них. Так, ефект “невидимості” виявляється в тому, що вчителі стверджують, що в їхніх школах i/або містах ЛГБТ-осіб немає і вони ніколи з ними не стикалися.

Феномен неусвідомлюваної нетолерантності проявляється в обов'язковому декларуванні власної толерантності 3 необов'язковим іiі усвідомленням, розумінням та дотриманням. Проте, на нашу думку, спроба людини виказувати толерантність уже свідчить про позитивні соціальні зрушення щодо сприйняття інакшості $\mathrm{i}$, до речі, тієї самої “видимості”.

Перспективи подальших досліджень убачаємо в дослідженні образу ЛГБТ-особи в різних групах та розробленні соціально-психологічної технології підвищення толерантності до різноманіття та інакшості.

\section{Список використаних джерел}

Кон, И. С. (2007). Гомофобия как лакмусовая бумажка российской демократии. Вестник общественного мнения. Данные. Анализ. Дискуссии, 4, 59-69.

Орлова, Ю., \& Осин, Р. (2019). Образ LGBT-сообщества в массовом сознании. Актуальные проблемы исследования массового сознания: материаль 5-й Международной научно-практической конференции. Пенза.

Осин, Р. (2019). Отношение к образу ЛГБТ-сообщества у представителей различных социально-демографических групп в России. Общество: социология, психология, педагогика, 11, $107-111$.

Ушакова, И., \& Киреев, Е. (2017). Трансгендерность в современном российском обществе. Мониторинг общественного мнения: экономические и соииальные перемены, 2, 82-96.

Florack, A., Scarabis, M., \& Gosejohann, S. (2005). The effects of self-image threat on the judgment of out-group targets. Swiss Journal of Psychology, 64(2), 87-101.

Lamar, L., \& Kite, M. (1998). Sex differences in attitudes towards gay men and lesbians: A multidimensional perspective. The Journal of Sex Research, 35, 189-196.

Nama, N., MacPherson, P., Sampson, M., \& McMillan, H.J. (2017). Medical students' perception of lesbian, gay, bisexual, and transgender (LGBT) discrimination in their learning environment and their selfreported comfort level for caring for LGBT patients: a survey study. Medical Education Online. Retrieved from https://doi.org/10.1080/10872981.2017.1368850. 
Nцlke, A.-I. (2018). Making Diversity Conform? An Intersectional, Longitudinal Analysis of LGBTSpecific Mainstream Media Advertisements. Journal of Homosexuality, 65(2), 224-255.

Skinner, M. D., \& Goodfriend, W. (2009). Perceptions of positive relationship traits in gay and lesbian couples. Journal of Homosexuality, 56(3), 319-335.

\section{References}

Florack, A., Scarabis, M., \& Gosejohann, S. (2005). The effects of self-image threat on the judgment of out-group targets. Swiss Journal of Psychology, 64(2), 87-101. (in English)

Kon, I. S. (2007). Gomofobiya kak lakmusovaya bumazhka rossiyskoy demokratii [Homophobia as a litmus test for Russian democracy]. Vestnik obshchestvennogo mneniya. Dannyye. Analiz. Diskussii, 4, 5969. (in Russian)

Lamar, L., \& Kite, M. (1998). Sex differences in attitudes towards gay men and lesbians: A multidimensional perspective. The Journal of Sex Research, 35, 189-196. (in English)

Nama, N., MacPherson, P., Sampson, M., \& McMillan, H.J. (2017). Medical students' perception of lesbian, gay, bisexual, and transgender (LGBT) discrimination in their learning environment and their selfreported comfort level for caring for LGBT patients: a survey study. Medical Education Online. Retrieved from https://doi.org/10.1080/10872981.2017.1368850. (in English)

Nulke, A.-I. (2018). Making Diversity Conform? An Intersectional, Longitudinal Analysis of LGBTSpecific Mainstream Media Advertisements. Journal of Homosexuality, 65(2), 224-255. (in English)

Orlova, Yu., \& Osin, R. (2019). Obraz LGBT-soobshchestva v massovom soznanii [The image of the LGBT community in the mass consciousness]. Aktualnyye problemy issledovaniya massovogo soznaniya: materialy 5 Mezhdunarodnoy nauchno-prakticheskoy konferentsii. Penza. (in Russian)

Osin, R. (2019). Otnosheniye k obrazu LGBT-soobshchestva u predstaviteley razlichnykh sotsial'nodemograficheskikh grupp $\mathrm{v}$ Rossii [Attitude towards the image of the LGBT community among representatives of various socio-demographic groups in Russia]. Obshchestvo: sotsiologiya, psikhologiya, pedagogika, 11, 107-111. (in Russian)

Skinner, M. D., \& Goodfriend, W. (2009). Perceptions of positive relationship traits in gay and lesbian couples. Journal of Homosexuality, 56(3), 319-335. (in English)

Ushakova, I., \& Kireyev, Ye. (2017). Transgendernost v sovremennom rossiyskom obshchestve [Transgender phenomenon in modern Russian society]. Monitoring obshchestvennogo mneniya: ekonomicheskiye i sotsialnyye peremeny, 2, 82-96. (in Russian) 